\title{
The Effect of Using A Blog as Reporting Media of Weekly Reading in Blended Learning Environment
}

\author{
Ufia Rahmi \\ Department of Educational Technology \\ Universitas Negeri Padang, Indonesia \\ ulfia@fip.unp.ac.id \\ Syafril \\ Department of Educational Technology \\ Universitas Negeri Padang, Indonesia \\ syafril@fip.unp.ac.id
}

\author{
Zuliarni \\ Department of Educational Technology \\ Universitas Negeri Padang, Indonesia \\ zuliarni59@gmail.com \\ Azrul \\ Student of Doctoral Program \\ Department of Educational Science \\ Universitas Negeri Padang, Indonesia \\ azrulmardin@unp.ac.id
}

\author{
Azman \\ Department of Educational Technology \\ Universitas Negeri Padang, Indonesia \\ azman2159@gmail.com
}

\begin{abstract}
The purpose of this paper is to verify the effect of using a blogfolio by collage students as weekly reading reporting media. The data were collected through experiment quantitative by pre-test post-test design. The method was done to 42 students in Educational Technology, Education Faculty, Universitas Negeri Padang at Development of Innovative Instructional Model Course. This result showed that way had significant effect on students learning outcome. The implications of using a blogs as per weekly reporting media require minimal computer skills, managing blog pages, and internet, to provide the widest possible opportunity to participate in improving message processing.
\end{abstract}

Keywords: blog, innovative learning, blended learning environment, reading, reporting media

\section{INTRODUCTION}

Education aims to prepare learners to survive (survivor) at this time and future. At a certain education level, the educational process of course aims to prepare students to survive in the higher levels. Likewise with the college, the learning process should encourage the development of all students' potential to be able to survive in the next stage. It can be done by designing challenging lessons and preparing them with skills relevant to present and future time. Universitas Negeri Padang as one of the universities that produces educators and educational staff has provided facilities such as 24hour free internet access, webmail, and e-learning for learning platform, and academic portal to support learning. With the facility, lecturers and students can be involved in e-learning or online learning.

Online learning is one part of e-learning, [1] states that e-learning is a type of learning that allows the delivery of teaching materials to students by using Internet-based media, internet or other computer network media. This opinion means that the availability of internet network at Universitas Negeri Padang enables the implementation of online learning. This learning is a form of learning implementation in accordance with National Standards of Higher Education based [2] Learning in Higher Education has principles that are interactive, holistic, integrative, scientific, contextual, thematic, effective, and student-centered. The implementation of innovative learning also has an interactive principle that enables the interaction between material sources so that the learning process is centered on the students.

Based on preliminary data, it turns out that students in Education Technology Study Program are quite close to the development of technology and information. Students have been able to operate computers and internet well. However, optimization of information technology and communication in learning activities is needed, to support the teaching and learning process. Learning activities are quite interesting by involving the active role of students in learning. Nevertheless, learning innovations are always and continuously needed to be done, including in Innovative Learning Model Development subject. One of the facilities of the internet that can be used as a medium of learning is a weblog. Innovation is utilizing blogs as a media reporting weekly reading by students. During this time, blogs developed by lecturers to submit materials and students access it in accordance with the instructions given. The innovation in this article is the blog created and used by each student in lieu of reading reports (resume) are collected every week.

Blogs appear from the term of weblog. Blog actually began to be known since 1997, but popular in 2000. Blog is a form of web application that resembles 
the writings (which is published as a post) on a public web page. Weblogs are personal web pages written in sequence and managed through specific software. From an educational point of view, weblogs are the development of conventional learning notes for students and lecturers, either as a conventional learning catcher or as an e-learning lesson.

Blogs can be said as effective learning media if they are properly managed so they can fulfill the teaching material principles, namely a) truth, b) in accordance with the child's development, c) up to date, d) balance between breadth and depth of material. The role of lecturers in building a learning culture through blogs is very important. The motivation of students to pour their ideas through blogs is not separated from the support of lecturers as educators. Educators can also direct the discussion and comments about the material or writings made by the students. In addition, lecturers can also deliver a material or task through the blog.

Implementation of e-learning is done in lectures conducted by utilizing blog facility. The blog technology enables interaction in this subject to be studied by [3] in his research article entitled Development of a Blended Instructional Model via Weblog to Enhance English Summary Writing Ability of Thai Undergraduate Students. In his research is to develop a blended learning model through weblog to improve the ability to write an English summary for undergraduate students of Thailand. His research was conducted in the English language course of Nakhon Ratchasima Rajabhat University in the academic year 2010-2013. Summary of writing through weblog consists of three activities in the writing process; The preparation, review and revision, and editing of publishing on the weblog consist of uploading files, studying comments, selecting possible comments, and visiting friends' blogs. The model is effective in improving students' writing abilities because the comparative value of pretest score with student posttest meets the criteria specified in the study.

Learning with blogs is also studied by [4] who examines the use of Weblog in Cooperative Learning to improve the learning of Student History. The study departs from a lack of interest and low achievement values in History learning. The study also examined the effectiveness of Weblog Cooperative Learning in improving students' understanding of a subject. This is also in line with a study by [5] in an article entitled The Effects of Paper-based Portfolios and Weblog-based Electronic Portfolios on Limited English Proficiency Students in Writing for Service Industry Course. [5] wanted to know the effect of using paper-based papers and weblog-based writing ability of students with limited English proficiency. The study was conducted with 60 first class hotel and tourism students enrolled in Writing for the Services Industry course. They have limited English skills. Google's free weblog site (located at www.blogger.com) is used as a tool for creating and developing a student's personal electronic portfolio. It was found that the effect of paper-based portfolios and weblog-based electronic portfolios on writing achievements was not significant. Therefore, it is necessary to prove the influence of blogs as a media reporting of weekly readings by students in a blended learning environment.

\section{METHOD}

This research is an experimental research with pretest-posttest design to prove the influence of blog usage by students in blended learning environment before and after applied. The procedure is to design the learning, know the initial state by doing pretest; students create and report weekly reading to each blog for half a semester, and do posttest. The use of blogs as a weekly reporting media by students applied to Innovative Learning Model Development courses, Education Technology Study Program, Faculty of Education, State University of Padang semester from January to June 2017.

Sample selection technique in this research through total sampling technique All the students enrolled in Innovative Learning Model Development courses become the sample in this research, which is 42 students. The technique of data collection is by giving the test given before and after treatment. The instrument used is a test that is built from four indicators, namely 1) innovative learning, 2) learning model and development model, 3) learning model component, 4) group of learning model including individual learning model, social, behavior change and processing Information [6] The instrument used is a valid and reliable instrument.

Furthermore, the data have been obtained is tested normality so that obtained value of significance of 0.323 . The value is greater than 0.05 so it can be concluded that the data of student learning outcomes in the course of Development of Innovative Learning Model normal distribution. Then do data analysis with t-test (independent test) to test difference of pre-test with posttest. The sample is 42 students, but one sample cannot be continued, so the data can be analyzed to 41 students.

\section{RESULT AND DISCUSSION}

This study aims to prove the influence of the use of blogs by students as a media reporting weekly reading in a blended learning environment in Innovative Learning Model Development courses. The results of stainless calculations can be seen in Table 1 and 2 .

Based on the Table 1 and 2 it is known that the value of Sig ( 2 Tailed) $0.000<0.005$, it means that there is a significant influence of the application of blogs by students before and after implementation.

This study shows that learning in blended learning environment using blogs improves student creativity. The process of processing information, pouring ideas and creativity of students on the blog is a meaningful experience for students. Learning through real-world experience helps they acquire soft skills and knowledge that are also useful in other subjects.

Learning in a blended learning environment by utilizing blogs is one of many online technologies that can be learned to improve and develop a better learning environment for students. It is important for educators to diversify learning strategies to make learning more meaningful and achieve a higher level of thinking [7]. The results of [3], [4] and [5] presented in the introduction can be seen that the role of e-learning can improve the quality 
of learning. Results of research conducted [3] weblog technology can increase interaction between students, lecturers and also information sources. Interactivity is a requirement in the use of e-learning according to [8]. For implementation, the principles that must be considered by users in doing e-learning include: 1) easy to use, 2) interactivity, 3) multiple expertise, 4) Collaborative, 5) authentic, and 6) student control..

Table 1. Statistical Data Result

\begin{tabular}{|l|l|l|l|c|c|c|c|}
\hline & & Mean & $\mathrm{N}$ & Std. Deviation & Std. Error Mean & Correlation & Sig. \\
\hline Pair 1 & pretest & 53,66 & 41 & 18,171 & 2,838 &, 062 &, 702 \\
\hline & posttest & 82,00 & 41 & 11,472 & 1,792 & \\
\hline
\end{tabular}

Table 2. Paired Test Result

\begin{tabular}{|c|c|c|c|c|c|c|c|c|c|}
\hline & \multicolumn{5}{|c|}{ Paired Differences } & \multirow[b]{3}{*}{$\mathrm{t}$} & \multirow[b]{3}{*}{ df } & \multirow[b]{3}{*}{ Sig. (2-tailed) } \\
\hline & & \multirow[b]{2}{*}{ Mean } & \multirow[b]{2}{*}{ Std. Deviation } & \multirow[b]{2}{*}{ Std. Error Mean } & \multicolumn{2}{|c|}{$\begin{array}{c}95 \% \text { Confidence Interval of } \\
\text { the Difference }\end{array}$} & & & \\
\hline & & & & & Lower & Upper & & & \\
\hline Pair 1 & $\begin{array}{l}\text { pretest } \\
\text { posttest }\end{array}$ & $-28,341$ & 20,883 & 3,261 & $-34,933$ & $-21,750$ & $-8,690$ & 40 & ,000 \\
\hline
\end{tabular}

This study has proven the effectiveness of the use of blogs as a media reporting weekly reading on the environment blended learning [9]. However, what needs to be studied is the implementation of blog-based learning with a minimum of 40 computers in each laboratory. Although full of limitations, now, every day, every home at least already has a computer and can be accessed with broadband and internet. Students are exposed to technology products faster and younger than the infrastructure of educational institutions. Dedicated educators or lecturers are urged to capture and optimize the proliferation of technology-based learning platforms for teaching and learning activities, whether provided by campus or individuals. Therefore, more productive use will be implemented in the future. Hopefully, more research will be done to provide more insight into the potential of technology in education. Research and development in this field should be continued with the aim of improving the practicality and suitability of the blog learning environment so as to meet all expectations to support and enhance learning in a blended learning environment.

\section{CONCLUSION}

Using blogs in a blended learning environment improves learning in Innovative Learning Model Development courses significantly. The implications of the students need to be given space to work more than usual by focusing on the use of technology. Lecturers need to design innovative learning designs to improve student interaction with technology and information substance.

\section{REFERENCES}

[1]. Fitria, Desi; Susilo, Boko; Farady, Funny. (2014). Elearning Kriptografi dengan Virtual Class Berbasis Multimedia. Jurnal Rekursif, Vol 2 No 1,page 10-18

[2]. Peraturan Pemerintah no 32 tahun 2013 tentang Standar Nasional Pendidikan. Download

[3]. Saisunee (2013). Development of a Blended Instructional Model via Weblog to Enhance English Summary Writing Ability of Thai Undergraduate Students. IAFOR Journal of Education, Vol 3, p 123-138

[4]. Leng, Lim Hoi; Leng, Chin Hai. (2013). Using Weblog in Cooperative Learning to Improve the Achievement of History Learning. Malaysian Online Journal of Educational Technology, Vol 1 no 3, p 30-43

[5]. Wanchid, Raveewan; Charoensuk, Valaikum. (2015). The Effects of Paper-based Portfolios and Weblog-based Electronic Portfolios on Limited English Proficiency Students in Writing for Service Industry Course. English Language Teaching, Vol 8, no 9, pp 131-145

[6]. Joyce, Bruce. Weil, Massha. \& Calhoun, Emily. (2009). Models of Teaching (8th). United Stated of America: Person Education, Inc.

[7]. Rahmi, Ulfia, et al. "Instructional Design using Blogs for Improving Learning Interactivity: A Design Case in Early Childhood Teacher Education Program." International Conference of Early Childhood Education (ICECE 2017). Atlantis Press, 2017.

[8]. Khan, B. H. (2005). Managing e-learning: Design, delivery, implementation, and evaluation. Hershey, PA: information science publishing

[9]. Rahmi, Ulfia, and Deni Darmawan. "Blog Folio in Blended Learning: a Development of Students' Information Processing Skills in Digital Age." Al-Ta lim Journal 25.2 (2018): 128-134 